\title{
Petition and Judicial Integrity
}

\author{
Zhuoyan Xie \\ School of Law \\ China University of Political Science and Law \\ Beijing 102249, China \\ E-mail: cherylxzy@gmail.com
}

\begin{abstract}
The petition system (Xingfang) is one of the greatest dilemmas in China's legal framework. Chaos was created as a result of the clash between it and the judicial system. This article is divided into three sections to analyze the interaction between petition practice and judicial integrity. The first section will identify the factors limiting judicial independence in mainland China, which is the main reason for the swelling number of petitions. Further, the characteristics leading to the failure of the petitioning system will also be explored. In the second section, the author will go on to explain the inherent conflict between the petitioning system and judicial integrity. In conclusion, the article draws together all the above strands into an overall analysis contending that the misplaced functions of petition practice should be redefined and a comprehensive reform is imperative.
\end{abstract}

Keywords: Xinfang, Judicial independence, Social grievance

\section{Introduction}

Raging debates are going on in mainland China about the petition system (Xingfang), one of the greatest dilemmas in China's legal framework.

As an indigenous cultural and legal tradition in China, the petitioning system was reestablished by the Chinese Communist Party in the 1950s. Since 1990s, a web of regulations has been passed by the Chinese authorities to govern petition practice. Despite the developments, petitioning practices still exist uneasily alongside with China's formal legal institutions because the two means of redress often parallel, overlap with each other in resolving individual grievance. (Note 1) By saying formal legal channels, here they mean judicial redress, administrative litigation, and other legal forums whose authorities and decision are primarily based on formal law and legal norms. On the contrary, the petition system derives their influence mainly from the political power of individuals. (Note 2) In imperial China, petition is premised on appeals by commoners to the better nature of their rulers, a plea for the protection of one's superiors.(Note 3) As the modern version of petition system, Xinfang is multi-purposes political governance tool, rather than an institution of popularized justice based legal norms.(Note 4)

Nevertheless, given the institutional weakness of China's judicial system, Xinfang remains a popular channel for dispute resolution. However, such a phenomenon generates enormous chaos that threatens the foundation of judicial independence.

Fundamentally, Petition practice comprehensively reflects the problems of China's legal and political framework concerning state accountability and legitimacy. However, this article will focus on the interaction between petition practice and judicial integrity, which the author considers the major source of contradictions.

The article is divided into three sections. The first section will identify the factors limiting judicial independence in mainland China, which is the main reason for the swelling number of petitions. Further, the characteristics leading to the failure of the petitioning system will also be explored. In the second section, the author will go on to explain the inherent conflict between the petitioning system and judicial integrity. In conclusion, the article draws together all the above strands into an overall analysis contending that the misplaced functions of petition practice should be redefined and a comprehensive reform is imperative.

\section{Petition or Litigation?}

Although, petition practice is just one of the many forums to redress grievance, however, in reality, the petition system is commonly viewed as a special power superior to formal legal channels. (Note 5). Nowadays, Xingfang practice permeate almost very government institutions, including those based on formal legal norms, like courts and procuratorates (Note 6).

Statistics show that the number of petitions has consistently exceeded that in judicial process. In the first nine months of 
2002, letters and visits to Party and government xinfang bureaus at the county level or higher totaled 8,640,040, corresponding with an annual rate of 11.5 million per year. (Note 7) In comparison, the entire Chinese judiciary handles six million legal cases annually.(Note 8) Even within the judiciary, use of Xingfang also outweighs formal procedures. According to the 2003 Work Report of the Supreme People's Court, the entire Chinese judiciary handled forty two million petitions during the preceding five years, compared with approximately thirty million formal legal cases.(Note 9)

\subsection{Reasons for Petitioning: All about Judicial Independence}

There are two reasons for people to turn to petition when their grievance could have been resolved in courts. The first reason is that the systematic lack of fair trials in China has led to a widespread lack of faith in the court system. Some petitioners said they did not even attempt to take their cases to court because they did not believe the court can maintain its impartiality and independence.(Note 10) Ironically, the other reason for people to petition is to take advantage of the lack of independent in judicial system. Petition system offers petitioners a possibility to influence court rulings before, after, or in the middle of the judicial proceedings.

\subsubsection{Seeking Alternative after Frustrations with the Lack of Judicial Independence.}

Although the constitution prescribes that "the people's courts shall, in accordance with law, exercise judicial power independently",(Note 11) the factors limiting independence of the courts are apparent.

From the personnel management point of view, although the judges shall be elected by the people's congress in accordance with law,(Note 12) the common practice is that they are nominated and appointed by their own courts or government units. What the people's congress usually does is simply rubber-stamping nominations approved by the party. In no case are judges elected by ordinary citizens. (Note 13) Furthermore, there is no life tenure for judges, Communist party's personnel office has the power to discipline or dismiss the judges for violation of party's cardinal regulation.(Note 13) Rules Governing the Behaviors of Judges also prescribe that judges shall have a steady political view, in which supporting the leadership of the Party is of outmost importance.(Note 14) The worst side of such supervision is that it is not carried out based on law nor has formal procedures, which eventually leaves the judges' work scrutinized by only a handful of men who might be in the interest of intervening court process. The courts often refused to act when the case is so sensitive that it might render the judges vulnerable to contradictions with government interests.

Another factor that undermines the independence of judicial system in China is regional power. As a matter of fact, local governments control the budgets of local courts, and very often a judge is appointed by local government units as I mentioned before. A study of hundreds of legal cases over 20 years, from 1979 to 1999, revealed that a court ruling was more likely to favor the local party when the lawsuit also involved a party from a different region. Minxin Pei, senior associate and co-director of the China Programme for the Carnegie Endowment for International Peace, conducted the study.(Note 15) Therefore, a systematic dysfunction of the judicial system is created due to the lack of independence. As a result, more and more people turn to the petitioning system when their cases should have been dealt with by the courts.

\subsubsection{Taking Advantage of the Lack of Independence.}

Talking of the lack of judicial independence, it immediately brings to mind images of influential senior officials making persuasive calls to judges. The cynical scenario often occurs in reality. Despite repulsion in the eye of scholars and other intellectuals who understand the significance of judicial independence, such a phenomenon are often applauded rather than frowned upon by the public. For example, when the case broke in Guangzhou that a graphic student Sun Zhigang was beaten to death during his custody at a police-affiliated clinic, intervention from higher authorities put pressure on the court so that justice was served in favor of the politically powerless migrant worker rather than the local police. Very few media commentators saw it as an erosion of judicial independence. Instead, they deemed it a variation of "divine intervention". Tian Wenchang, a defense lawyer, wrote many letters appealing to various government agencies to intervene on behalf of his client. "I'm against administrative intervention and all for judicial independence. Everyone knows that intervention is bad for justice. But when one runs out of other forms of recourse, one has to rely on it. This is a vicious circle and it is sad," he complains. (Note 15)

Moreover, existing laws governing judicial system provide incentives to petition practice when citizens are unsatisfied with court decisions. Firstly, there is an expansive and ill-defined retrial procedure known as trial supervision process. This procedure allows multiple actors, including parties, the procuratorates, and higher courts, significant leeway to request or compel the reopening of final court decisions. (Note 16) Secondly, a judicial "responsibility system" analogous to those in government organs create incentive structures conducive to petitioning behavior. Commonly known as "responsibility systems for wrongly decided cases" (cuo an zeren zhuijiu zhi), this internal disciplinary codes punish judges for a wide range of behavior, one of which is the repeated petitions o higher-level authorities. Lots of petitioners try to utilize such a mechanism to press the judges to rule favorably on their behalf by petition up the 
hierarchy. (Note 17) Finally, the constitution of PRC specifies that the petition bureaus are in charge of supervising the work of both courts and administrative organs. In practice, these petition bureaus may also avail themselves of the power of supervision to affect the disposition of court cases.(Note 18) All these factors manifest that China's judicial system is severely tainted by external influence, which is also the reason why petition practice proliferates.

\subsection{Is Petition an Alternative?}

The number of petitions continues to swell over years, most of which should have been resolved and finalized by the courts. Therefore, the petition system's major functions are gradually displaced as an alternative to judicial relief, a role that is impossible for it to fulfill. The reason is straightforward. When the constitutionally mandated independence is not built into the judicial system, there is little chance that the petitioning system, an institution based on personal power, can ever ensure justice in redressing grievance. In this section, the genetic flaws of Xinfang will be elaborated.

\subsubsection{Lack of Substantive Rules}

First of all, the petitioning system lacks substantive rules to make it function effectively. Although a national regulation passed in 2005 does establish a procedural framework, which includes time frame, ways of responses, and penalties.(Note 19) Still, little guidance is provided on how petition bureaus are expected to resolve individual petitions that are transferred to them. Critical issues are left unaddressed, including, the substantive and procedural criteria one should apply to the review process, the ability of administrative agencies to compel compliance from other entities during the process, the rights of the petitioners, and the actual effect of any decision reached. (Note 20) According to the observation of some scholars, the Xinfang institution is not even designed to resolve individual grievance on a regular basis, rather, it is designed only to respond to certain types of petitions — - in particular, organized, repetitive, or large scale ones.(Note 21) However, none of the terms therein mentioned is clearly defined. In the words of one municipal public security official, "......leadership directives, administrative orders, and internal digestion remain the main methods for carrying out xingfang work."(Note 22)

\subsubsection{Lack of Impartiality and Independence.}

Further, the petitioning system is doomed to fail because it does not have the necessary elements of impartiality and independence. In practice, the system encompasses petitions offices for a number of government agencies at every level of the country. They can be a separate office inside a government bureau or Communist Party office, or merely a desk within a local government.(Note 23) Officials in charge often have a disincentive to process complaints about their misdeeds or those of their colleagues. That is why success for petitioners is quite rare. A 2004 study by a Chinese professor, Yu Jianrong of the Chinese Academy of Social Sciences, found that of the two thousand petitioners surveyed; only three had their problems resolved. Less than two out of a thousand petitioners who take their cases to national-level petitioning offices ever receive a written response.(Note 24) Moreover, there are no publicly established criteria upon which decisions are made, no system of publishing decisions with legally sound explanations. All of these factors made it impossible to ensure fairness.

\subsubsection{Lack of Effective Remedies}

Moreover, there are hardly any effective remedies from petition practice. The xinfang regulations only grant xinfang bureaus a degree of "soft" dispute resolution power, which include the authority to engage in mediation of disputes raised in petitions, (Note 25) and to propose corrective measures and administrative punishments for government agencies and individuals' derelict in their handling of petition work.(Note 26) The responses normally take the form of letters from a higher authority to a lower one. However, it is generally acknowledged that such a response has absolutely no actual power to compel action. Although China's government is hierarchical, and local authorities must answer to their superiors, on matters that are not considered a governmental or Party priority, national-level authorities often have little direct control over low-level officials at the county, township and village level. A letter from a superior authority to a local official does not compel a response, and some local officials simply choose to disregard them.

However, the failure of Xinfang to serve as an alternative to judicial relief does not point to the conclusion that it should be strengthened, or be made a real political entity with greater power. In fact, from the perspective of establishing the rule of law in China, the petitioning system does more harm than good even if it is formalized. Just as a scholar suggests, "the petitioning system is inborn with the rule of man",(Note 27) and the expansion of it would only further erode the feeble judicial integrity in China

\section{XINGFANG does more harm than good}

Some people argue that Xinfang should be kept in place and strengthened because China's legal system is not in a good shape. However, the existence of xinfang actually makes the chance to establish an independent judiciary even smaller. The reasons are as follows.

\subsection{Xinfang Renders Judicial Process More Vulnerable to Manipulation}

To begin with, the petitioning system renders judicial process even more vulnerable to manipulation. As I have 
mentioned in the II part of this article, one of the reasons for the swelling number of petition is because of the external influence that xinfang has on judicial process. Many provincial Xinfang regulations explicitly provide that the petition bureaus have the authority to review court, government and procuratorate decisions.(Note 28) It practice, xinfang serves as an appeal process in additional to the normal judicial procedures, which weakens the finality of judicial process. As a principle, the judicial process in mainland China only allow one appeal to the next higher level court of the first trial, of which the decision will be binding and final.(Note 29) However, a "trial supervision process" could be initiated if a serious flaw was found, which is supported by the judicial principle "to seek the facts and always redress the wrongs".(Note 30) Furthermore, under existing law, the incentive for the courts to find such a flaw is unclear. In practice, an ultimate verdict could be overthrown by a decree of a higher authority, be that from a court or procuratorate of a higher level, an agency of legislative branch, or one from the administrative branch. And all of the above authorities have xinfang bureaus that the petitioner could turn to. Such a loophole is constantly exploited by petitioners. Therefore, people who get unfavorable ruling from the courts will try every desperate mean to get higher official to their side. Moreover, if petitioners are unsatisfied with the response to a petition they have the right to continue up the chain of petition bureaus all the way from the village level to the township, county, provincial, and national levels. After the ruling is overturned, the winner of the case becomes loser, who might go further up the hierarchy in petitioning system seeking another resettlement. Xinfang renders the outcome of judicial process even more unpredictable, and makes judicial system further tainted by unethical influence. Ultimately, it would lead to a breakdown of the overall credibility of the courts.

\subsection{Xinfang Undermines the Rule of Law}

Furthermore, the petitioning system undermines the foundation of the rule of law, which is a precondition for judicial independence. Although the petitioning system seems to have maintained hope for disadvantaged people who have suffered injustices, but as a matter of fact, it is like drinking poison to quench a thirst. Instead of being devoted to constructing a unified legal basis, it always tries to create exceptional precedence. (Note 31) One event that got enormous media coverage in 2003 was that Premier Wen Jiabao helped a migrant laborer get back defaulted wages. The kindness of our premier was highly sang again because of this story, which also leads petitioners to believe, as long as they can reach a high ranking official, they can get their problem solved. But in fact, no matter how wise and loving our senior officials are, they can only handle very limited number of cases and there is no guarantee for the fairness of such handling. Sadly, the chance of getting exceptional personal attention is exactly what the petitioning system is premised on. As a well-acknowledged principle, the foundation of judicial independence is a set of rules that does not only solve individual cases but also offers a legal basis for ruling on other cases.(Note 31) Only if that is in place can the judicial system function independently, using its own logic to judge cases without influenced by external power. But as a relic from feudal society, the petitioning system is basically about getting personal favor from a monarch or senior official. Despite its positive effect on a few cases, the side effect is tremendous; it pushes our judicial system further away from the rule of law, but closer to the rule of man. (Note 31)

\section{Conclusion}

As a conclusion to this paper, this section will point out the major problems concerning the relation between Xinfang and judicial independence, and a general solution will be proposed hereinafter.

\subsection{What Goes Wrong?}

Vicious circles are formed as a result from the interaction between Xinfang and the judicial system in China, which aggravates social tension and leads to a breakdown of the overall credibility of the government.

\subsubsection{From an Institutional Prospective}

Due to the absence of judicial independence in China's legal system, a systematic lack of fair trials has resulted in an uncontrollable proliferation in petitions, which is viewed as an alternative path to justice. Unfortunately, given the characteristics differing significantly from what might be expected from rule of law, Xinfang is by no mean a competent substitution to formal legal channels of redress. Even worse, Xinfang practice renders judicial process even more vulnerable to manipulation, which concentrates to become another disaster to the feeble judicial integrity in China.

Consequently, a vicious circle is formed:

The Lack of Fairness in Judicial Process $\rightarrow$ Proliferation of Petitions $\rightarrow$ Further Erosion on Judicial Integrity

\subsubsection{From a Social-State Perspective}

Mainstream discourse has all along proclaimed that the petition system aims at easing social tension, however, social grievance are actually amplified instead of eased.

As I have mentioned before, Xinfang lacks the essential ingredients to make it function as an institution of popularized justice. However, people turn to it in hope of have their grievance solved effective, which normally ends up in frustration. And accumulated frustration could be a major threat to social stabilities. 
Moreover, the existing petition system maintains unreasonable hope for people who suffer injustice, examples include Xinfang's power to influence or to overthrow court rulings. Many petitioners spend years of their lives trapped in the petitioning system in the belief that a decision in their favor will justify the time spent in the effort. Some families become petition dynasties, doing nothing but petitioning. Accumulated grievance eventually turns into obsession. Devastating psychological effect resulted from prolonged lawsuits is not unique to China. Contemporary parallels exist in many countries: a U.S. reporter writing about long-term appellants for alimony in New York City observes, "In their seemingly endless court battles, litigants on both sides often become overwhelmed, depressed, or if they are going to become at all successful, obsessed."(Note 32) It is reported that raging anger towards government grows increasingly strong in mass petitioners.

On the side of government, although it is proclaimed that Xinfang is "a bridge for the party and government to connect with the masses, a window to listen to the voice of the masses, and an important channel for reflecting the sufferings of the masses;" Yet the government and Party display an increasingly contradictory and inconsistent attitude towards petitioners. Human right violations are widely reported in government's dealing with petition,(Note 33) which turns petition system into a new creator of social conflicts.

However, in a country without a free media or an accountable judicial system, petition remains a popular channel for expressing grievance. Therefore, another vicious circle is formed, which could leads to an overall breakdown of government credibility.

Intensive Social Tension $\rightarrow$ Proliferation of Petitions $\rightarrow$ Amplification of Social-State Conflict

\subsection{Suggestions}

It is no easy task to untangle the deadlock resulted from the clash between Xinfang and the judicial system in China. Considering the political complication, the author does not aspire to give a detailed plan of reform, instead, a general solution will be proposed.

Fundamentally, a flawed judicial system can only be remedied by a reform of its own, instead of being substituted by an even less accountable mechanism like the petitioning system. In regard to a judicial reform in China, the most important aspect is to restore independence to the judiciary. And the key to independence is to have law as the only basis for trialing cases, and to keep the external influence to the minimum.

In China, it is very important to make sure that the supervisions over the judges are conducted with most prudence. As I have mentioned in the second part of this essay, most disturbances to the neutrality of the judges are in the name of supervisions, especially those from the Communist Party. Most of these supervisions lack transparency and are not conducted in accordance with substantive law or formal procedures. Consequently, it is very convenient for a supervisory body to affect the disposition of a court case by exerting pressure on the judges. Therefore, in order to restore fairness and independence to the judicial process, I recommend formalize supervision over the judges. In particular, supervision of the judges needs to be restricted to an appropriate extent, and it should be conducted strictly on the basis of law instead of some personnel disciplines or political standards.

Moreover, Xinfang's influence on judicial process needs to be restricted. As I have mentioned in the second section of this article, many people turn to petition trying to take advantage of such a loophole. To be more specific, the conditions for initiating the retrial procedure should be restricted in order to ensure the predictability and authority of judicial decisions. Just as I have pointed out previously, such an endless appeal process can only renders the judicial process more vulnerable to manipulation and amplify social tension.

Further, the misplaced functions of the petitioning system need to be redefined. According to Carl F. Minzner, Xinfang is a critical multi-purposes governance tool for an authoritarian state, whose functions include connecting the government with the people. (Note 34) Given the limited freedom of expression and public participation in China, Xinfang remains a very important mechanism to meet those needs. However, it is not suitable to serve as a substitution to the judicial process.

Ultimately, no serious progress towards judicial independence will be possible without fundamental reform. Essentially, all the problems therein mentioned are the result of a close political framework without grass root democracy. Therefore, Local and national governance structures have to be radically changed to allow for more popular participation and public accountability, which is a political decision that has to be taken at the highest levels of the government and Party.

\section{References}

Albert P. Melone. (1981). Judicial Independence in Contemporary China, Judicature.

Beijing Time, External Influence Complicates Court Ruling on Chinese Manfia Kingpin, $<$ http://en.chinaelections.org/newsinfo.asp?newsid=18691> accessed on Nov 15, 2008.

Carl F. Minzner. (2006). Xinfang: An Alternative to the Formal Chinese Legal System, Stanford Journal of 
International Law, vol. 42:1.

Chen Guidi and Chun Tao, (2004) An Investigation of China's Peasantry, People's Culture Press.

Cai Dingjian. (2004). The Basic Situation of LPC Individual Case Supervision. $<$ http://www.rdyj.com.cn/2004/rdqk-3-2.html> accessed in 2005.

He Weifang. (2005). Judicial Independence Should Come First, $<$ http://boke.xizhengren.com/15514/> accessed on Nov $18,2005$.

Human Rights Watch interview with Cai, Beijing. (2005). in "We Could Disappear at Anytime", $<$ http://www.hrw.org/reports/2005/china1205/4.htm\#_ftn22> accessed on Nov 1st, 2008.

Interview with Zhou Zhangshun, Director of State Bureau of Letters and Calls, Bimonthly Discussion $<$ http://www.china.org.cn/chinese/2003/nov/446032.htm > accessed on Nov 2003.

Leslie Eaton. (2005). Coping: Up the courthouse steps, and still climbing, New York Times, August 14, 2005, Section 14.

Liao Yiwu. (2005). Shantytown for Supplicants: Reports on China's Victims of Injustices, Hong Kong: Mirror Books.

Nanping Liu. (1999). A Vulnerable Justice: Finality of Civil Judgment in China, 13 Columbia Journal Asian Law.

Xu Jianying, Some Thoughts on Realizing Rule of Law in Xinfang Work, 6 J. Zhejiang Police C. Pub. Security Sci. J.

Yu Jianrong, (2005). A Survey of the Xinfang System and Thoughts on Reform, Analysis and Forecast on China's Social Development.

Yu Jianrong, Critique of the Petition System<http://www.yannan.cn/data/detail.php?id=4842> accessed on July 10, 2005 .

Yi Jianrong. (2008). Who bears the costs of intercepting petitioners? $<$ http://en.chinaelections.org/newsinfo.asp?newsid=18648> accessed on Nov 18th, 2008.

2002 Supreme People's Cout Work Report.

1982 Constitution of the People's Republic of China.

1983 Organic Law of the People's Courts of the People's Republic of China.

2005 Rules Governing the Behaviors of Judges, PRC.

2005 National Regulations on Letters and Visits

2003 Heilongjiang Province Xinfang Regulations.

2004 Xinfang Regulations of Zhejian Province, PRC.

1991 The Civil Procedure Law of PRC.

\section{Notes}

Note 1. Carl F. Minzner, (2006) Xinfang: An Alternative to the Formal Chinese Legal System, Stanford Journal of International Law, vol. 42:1, page 104.

Note 2. Carl F. Minzner, (2006) Xinfang: An Alternative to the Formal Chinese Legal System, Stanford Journal of International Law, vol. 42:1, page 139.

Note 3. For more on petitioning and related subjects, see, for example, Carl F. Minzner, Supra note 1; See also Liao Yiwu, Shantytown for Supplicants: Reports on China's Victims of Injustices, (Hong Kong: Mirror Books, 2005); as well as Chen Guidi and Chun Tao, An Investigation of China's Peasantry [People's Culture Press (Renmin Wenxue Chubanshe), 2004]; See also Kevin O’Brien, “The Politics of Lodging Complaints in Rural China," China Quarterly (1995).

Note 4. Carl F. Minzner, supra note1, page 107.

Note 5. Yu Jianrong, (2005) A Survey of the Xinfang System and Thoughts on Reform, Analysis and Forecast on China's Social Development, page. 212, 214-15.

Note 6. The Chinese procuratorate is a rough equivalent of 'district attorney office'; theoretically, they are independent from the government.

Note 7. Interview with Zhou Zhangshun, Director of State Bureau of Letters and Calls, Bimonthly Discussion $<$ http://www.china.org.cn/chinese/2003/nov/446032.htm $>$ accessed on Nov 2003.

Note 8. 2002 Supreme People's Court Work Report.

Note 9. 2003 Supreme People’s Court Work Report. 
Note 10. Human Rights Watch interview with Cai, Beijing, 2005, in "We Could Disappear at Anytime", $<$ http://www.hrw.org/reports/2005/china1205/4.htm\#_ftn22> accessed on Nov 1st, 2008.

Note 11. 1982 Constitution of the People's Republic of China, art 126.

Note 12. 1983 Organic Law of the People's Courts of the People's Republic of China, art 35.

Note 13. Albert P. Melone, (1998) Judicial Independence in Contemporary China, Judicature 81, page 257, 258.

Note 14. 2005 Rules Governing the Behaviors of Judges, PRC, art 1, (2).

Note 15.Beijing Time, External Influence Complicates Court Ruling on Chinese Manfia Kingpin, $<$ http://en.chinaelections.org/newsinfo.asp?newsid=18691> accessed on Nov 15, 2008.

Note 16. Nanping Liu, (1999) A Vulnerable Justice: Finality of Civil Judgment in China, 13 Columbia Journal Asian Law.

Note 17. Carl F. Minzner, supra note 1, page 139.

Note 18. See generally Cai Dingjian, The Basic Situation of LPC Individual Case Supervision (2004), $<$ http://www.rdyj.com.cn/2004/rdqk-3-2.html> accessed in 2005.

Note 19. See generally 2005 National Xingfang Regulations, PRC.

Note 20. Carl F. Minzner, supra note 1, page 127.

Note 21. For example, ibid, page 108.

Note 22. Xu Jianying, Some Thoughts on Realizing Rule of Law in Xinfang Work, 6 J. Zhejiang Police C. Pub. Security Sci. J, page 137.

Note 23. Regulations on Letters and Visits, supra note 16, Article 6.

Note 24. Yu Jianrong, Critique of the Petition System <http://www.yannan.cn/data/detail.php?id=4842> accessed on July 10, 2005.

Note 25. 2004 Xinfang Regulations of Zhejian Province, PRC, art 19.

Note 26. 2005 National Xingfang Regulations, art 37.

Note 27. He Weifang, Judicial Independence Should Come First, < http://boke.xizhengren.com/15514/> accessed on Nov 18, 2005.

Note 28. 2003 Heilongjiang Province Xinfang Regulations, art 23, 33.

Note 29. See for example, 1991 The Civil Procedure Law of PRC, art 158.

Note 30. See for example, Ibid, art 179.

Note 31. He Weifang, supra note 27.

Note 32. Leslie Eaton, Coping: Up the courthouse steps, and still climbing, New York Times, August 14, 2005, Section 14 , page 1 .

Note 33. Yi Jianrong, Who bears the costs of intercepting petitioners? < http://en.chinaelections.org/newsinfo.asp?newsid=18648>accessed on Nov 18th, 2008.

Note 34. See generally, Carl F. Minzner, supra note 1. 